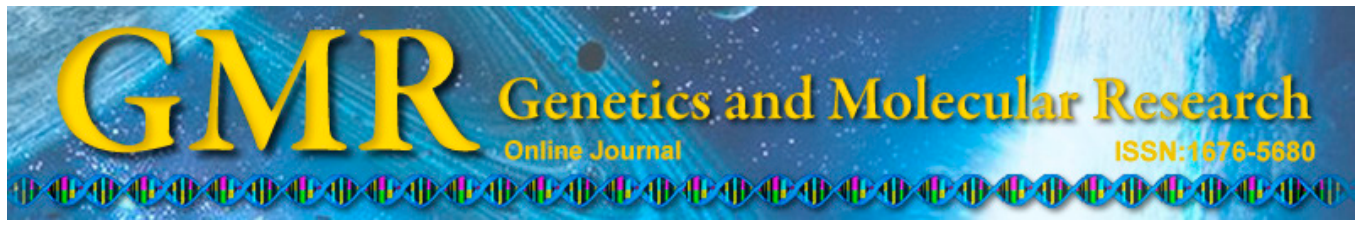

\title{
Comparison of extraction methods of total microbial DNA from freshwater
}

\author{
P. Li ${ }^{1,2}$, S.F. Yang ${ }^{1,2}$, B.B. Lv ${ }^{1,2}$, K. Zhao ${ }^{1,2}$, M.F. Lin ${ }^{1,2}$, S. Zhou ${ }^{3}$, X. Song ${ }^{3}$ \\ and X.M. Tang ${ }^{1,2}$ \\ ${ }^{1}$ Biotech Research Institute of Shanghai Academy of Agricultural Sciences, \\ Shanghai, China \\ ${ }^{2}$ Shanghai Key Laboratory of Agricultural Genetics and Breeding, \\ Shanghai, China \\ ${ }^{3}$ Institute of ECO-Environment and Plant Protection, \\ Shanghai Academy of Agricultural Sciences, Shanghai, China \\ Corresponding author: X.M. Tang \\ E-mail: sunsite@126.com
}

Genet. Mol. Res. 14 (1): 730-738 (2015)

Received January 3, 2014

Accepted April 3, 2014

Published January 30, 2015

DOI http://dx.doi.org/10.4238/2015.January.30.16

\begin{abstract}
The demand for molecular analysis of aquatic microbial communities in freshwater has highlighted the need for efficient methods of DNA extraction. The centrifugation method and filtration-membrane method are 2 widely used methods for extracting DNA. The objective of this study was to compare the extraction efficiency of 3 methods, including the centrifugation method, filtration-membrane method, and modified filtration-membrane method, by evaluating the quantity and purity of DNA extracts obtained from water. DNA extraction was analyzed by agarose gel electrophoresis, ultraviolet-spectroscopy, restriction enzyme digestion, and polymerase chain reaction. The results showed that the modified filtration-membrane method was the most efficient for extracting microbial DNA from freshwater with high integrity and purity and is suitable for molecular applications.
\end{abstract}

Key words: Extraction efficiency; Freshwater; Microbial diversity; Polymerase chain reaction; Total DNA 


\section{INTRODUCTION}

As primary components of material and energy recycling pathways, microbes are essential to all life on Earth, playing a particularly important role in freshwater environments. Analysis of microbial community structures, the characteristics of microbial distribution, and the function in aquatic ecosystems is important for ecological studies (Wu et al., 2010).

The conventional method for analyzing water microbial populations involves isolating and traditional culturing of microbes. However, this method is limited because few microbes can be effectively cultured in water. It was previously estimated that approximately 0.25 and 0.001-0.1\% microbes can be cultivated in freshwater and seawater, respectively (Amann et al., 1995). Because of the inherent limitations of culture-based methods, microbial ecologists have begun to develop culture-independent methods of community analysis. The use of culture independent methods circumvents the disadvantages of microbial isolation and culture, and the direct use of molecular biology methods increases the probability of identifying new microbes and analyzing the diversity present in the microbial community (Handelsman, 2004).

Therefore, extracting total DNA from water-dwelling microbes is very important. Currently, there are 2 types of methods for extracting total DNA from water microbes. First, microbe enrichment can be achieved using high-speed centrifugation (Zhang et al., 2012). Second, microbes can be absorbed and aggregated using a filtration membrane (Ye et al., 2009).

Before extracting DNA from freshwater organisms, a high concentration of microbes is required. The high-speed centrifugation method is the simplest and most cost-efficient method. However, the purity of extracted DNA is highest using the filtration membrane method. The compositions of freshwater environments are very complex and may contain chemical components, particularly humic acid, which inhibits the activity of enzymes such as restriction endonucleases and DNA polymerase (Mangiapan et al., 1996; Bürgmann et al., 2001; Dong et al., 2006). Further, the physico-chemical properties of humic acid and nucleic acids are similar, making it difficult to extract total DNA.

In this study, we compared 3 methods for extracting total microbial DNA, including the centrifugation method (Zhang et al., 2012), the filtration-membrane method (Ye et al., 2009), and the modified filtration-membrane method (developed in our laboratory), to determine the most suitable method for evaluating microbial community dynamics and the quantity and purity of DNA.

\section{MATERIAL AND METHODS}

\section{Collection of freshwater samples of rivers}

Freshwater samples were collected from the Huangpu River $\left(31^{\circ} 14^{\prime} \mathrm{N}, 121^{\circ} 29^{\prime} \mathrm{E}\right)$ in Shanghai on July 9, 2012. This river is used for irrigating rice and drinking water. The Huangpu River is a tributary of the largest river in China, the Yangtze River. The temperature, $\mathrm{pH}$, and concentration of dissolved oxygen in the water column at the time of sampling were $18.2^{\circ} \mathrm{C}, 7.7$, and $11.8 \mathrm{mg} / \mathrm{L}$, respectively. Freshwater samples were collected from $0.5 \mathrm{~m}$ below the surface using a Ruttner Standard Water Sampler (KC-Denmark A/S Company, Silkeborg, Denmark) and immediately transferred to a sterile bottle. All samples were transferred to the laboratory and stored at $4^{\circ} \mathrm{C}$. 


\section{Total microbial DNA extraction methods of freshwater organisms}

\section{Centrifugation method with slight modification}

This method was described previously by Zhang et al. (2012) and used with some modifications. The $50-\mathrm{mL}$ water sample was centrifuged at $5000 \mathrm{~g}$ for $20 \mathrm{~min}$ at room temperature. The precipitate was transferred to a $2-\mathrm{mL}$ centrifuge tube and $1.5 \mathrm{~mL} 1 \%$ hexadecyltrimethylammonium bromide (CTAB) buffer was added and mixed thoroughly. The suspension was incubated at $65^{\circ} \mathrm{C}$ for $20 \mathrm{~min}$. An equal volume of chloroform/isoamyl alcohol (24:1) was added and the sample was centrifuged for $10 \mathrm{~min}$ at $4^{\circ} \mathrm{C}$ at $13,000 \mathrm{~g}$. Next, $2 / 3$ volume isopropyl alcohol was added and the mixture was cooled at $-20^{\circ} \mathrm{C}$ for $15 \mathrm{~min}$. This sample was centrifuged for $10 \mathrm{~min}$ at $4^{\circ} \mathrm{C}$ at $13,000 \mathrm{~g}$ and the supernatant was discarded. Next, $700 \mu \mathrm{L} 70 \%$ ethanol was added, followed by centrifugation for $10 \mathrm{~min}$ at $4^{\circ} \mathrm{C}$ at $13,000 \mathrm{~g}$ to precipitate the DNA. The supernatant was discarded. After this step, $500 \mu \mathrm{L} 70 \%$ cold ethanol was added and the sample was centrifuged for $5 \mathrm{~min}$ at $4^{\circ} \mathrm{C}$ at $13,000 \mathrm{~g}$ and the precipitate was collected. The supernatant was discarded and the pellet was air-dried at $65^{\circ} \mathrm{C}$. Sterile $\mathrm{ddH}_{2} \mathrm{O}$ was added and the DNA solution was stored at $-20^{\circ} \mathrm{C}$.

\section{Filtration-membrane method with slight modification}

This method was described previously be Ye et al. (2009). The 50-mL water sample was filtered through a $0.22-\mu \mathrm{m}$ pore filter (diameter, $45 \mathrm{~mm}$; Millipore, New Bedford, MA, USA). The membrane was cut into $1-2 \mathrm{~mm}$ of the debris under sterile conditions, and debris was removed into a $2-\mathrm{mL}$ microcentrifuge tube. Next, $1.5 \mathrm{~mL}$ STET buffer $(8 \%$ sucrose, 50 $\mathrm{mM}$ Tris, $\mathrm{pH} 8.0,50 \mathrm{mM}$ EDTA, $0.1 \%$ Tween-20) was added to fill the tube and the sample was centrifuged for $5 \mathrm{~min}$ at $4^{\circ} \mathrm{C}$ at $10,000 \mathrm{~g}$. The supernatant was removed and $1 \mathrm{~mL}$ STET buffer was added, followed by centrifugation for $2 \mathrm{~min}$ at $4^{\circ} \mathrm{C}$ at $10,000 \mathrm{~g}$. The precipitate was collected. Next, $200 \mathrm{~mL}$ STET buffer and $4 \mu \mathrm{L} 50 \mathrm{mg} / \mathrm{mL}$ lysozyme were added and the sample was mixed for $5 \mathrm{~min}$ at room temperature. Proteinase K was added to a $100-\mu \mathrm{g} / \mathrm{mL}$ concentration and the sample was mixed and incubated for $1 \mathrm{~h}$ at $37^{\circ} \mathrm{C}$. After incubation, 0.5 $\mathrm{M} \mathrm{NaCl}$ and $25 \mu \mathrm{L} 5 \% \mathrm{CTAB}$ were added and the sample was incubated for $10 \mathrm{~min}$ at $65^{\circ} \mathrm{C}$.

To separate the DNA from the mixture, an equal volume of saturated phenol was added and the sample was centrifuged for $5 \mathrm{~min}$ at $4^{\circ} \mathrm{C}$ at $12,000 \mathrm{~g}$; the supernatant was transferred to a $1.5-\mathrm{mL}$ microcentrifuge tube. Next, an equal volume of phenol/chloroform/ isoamyl alcohol was added $(25: 24: 1, \mathrm{v} / \mathrm{v})$ and the tube was centrifuged for 5 min at $4{ }^{\circ} \mathrm{C}$ at $12,000 \mathrm{~g}$; the supernatant was transferred to a $1.5-\mathrm{mL}$ microcentrifuge tube. To the supernatant, an equal volume of chloroform was added, and then the sample was mixed and centrifuged for $5 \mathrm{~min}$ at $4^{\circ} \mathrm{C}$ at $12,000 \mathrm{~g}$; the supernatant was transferred to a $1.5-\mathrm{mL} \mathrm{mi-}$ crocentrifuge tube.

To this supernatant, $1 / 10$ volume $2 \mathrm{M}$ sodium acetate and 2 volumes cold ethanol were added, the sample was mixed well, and then cooled at $-20^{\circ} \mathrm{C}$ for $1 \mathrm{~h}$. After $1 \mathrm{~h}$, the sample was centrifuged for $10 \mathrm{~min}$ at $4^{\circ} \mathrm{C}$ at $13,000 \mathrm{~g}$ and the supernatant was discarded. Next, $500 \mu \mathrm{L} 70 \%$ cold ethanol was added and the sample was centrifuged for $5 \mathrm{~min}$ at $4^{\circ} \mathrm{C}$ at $13,000 \mathrm{~g}$ and the precipitate was collected. The pellet was air-dried at $65^{\circ} \mathrm{C}$; sterile $\mathrm{ddH}_{2} \mathrm{O}$ was added and the DNA solution was stored at $-20^{\circ} \mathrm{C}$. 


\section{Modified filtration-membrane method}

First, a $50-\mathrm{mL}$ freshwater sample was filtered through a $0.22-\mu \mathrm{m}$ hydrophobic polyvinylidene fluoride membrane (Sangon Biotech Co., Ltd., Shanghai, China). The membrane was cut into 1-2-mm sections under sterile conditions, and debris was removed to a $2-\mathrm{mL}$ microcentrifuge tube. Next, $1.5 \mathrm{~mL}$ STET buffer ( $8 \%$ sucrose, $50 \mathrm{mM}$ Tris, $\mathrm{pH} 8.0,50 \mathrm{mM}$ EDTA, $0.1 \%$ Tween-20) was added to fill the tube.

Second, $0.8 \mathrm{~g}$ sterilized zirconium beads (1.0-1.2 nm, Saint-Gobain Research Co., Ltd., Shanghai, China) was added and the sample was vortexed for 10 min by placing horizontally on a reciprocal platform shaker at high speed (approximately 100 oscillations/min) at room temperature. Next, $200 \mu \mathrm{L}$ STET buffer and $4 \mu \mathrm{L}$ lysozyme $(50 \mathrm{mg} / \mathrm{mL})$ were added and the sample was mixed for $5 \mathrm{~min}$ at room temperature. To the suspension, $6 \mu \mathrm{L}$ proteinase $\mathrm{K}(20 \mathrm{mg} / \mathrm{mL})$ and $30 \mu \mathrm{L}$ SDS $(10 \%)$ were added and the sample was incubated for $10 \mathrm{~min}$ at $37^{\circ} \mathrm{C}$. After incubation, $1 / 6$ volume $5 \mathrm{M} \mathrm{NaCl}$ and $1 / 9$ volume CTAB (final concentration of $5 \%$ ) were added, followed by incubation for $10 \mathrm{~min}$ at $65^{\circ} \mathrm{C}$. After this step, $200 \mu \mathrm{L}$ phenol/ chloroform/isoamyl alcohol $(25: 24: 1, \mathrm{v} / \mathrm{v} / \mathrm{v})$ was added, the sample was vortexed, and the tube was centrifuged for $5 \mathrm{~min}$ at $4^{\circ} \mathrm{C}$ at $15,000 \mathrm{~g}$. The upper (aqueous) phase was transferred to a 2.0-mL microcentrifuge tube.

To this layer, 0.7 volumes isopropanol was added to precipitate the nucleic acids and the tube was incubated at room temperature for $10 \mathrm{~min}$. The sample was centrifuged for 15 $\mathrm{min}$ at $12,000 \mathrm{~g}$ at room temperature and the isopropanol was carefully removed. The remaining pellet was resuspended in $50 \mu \mathrm{L}$ TE buffer (10 mM Tris-HCl, $1 \mathrm{mM}$ EDTA, pH 8.0), 5 volumes GES reagent ( $5 \mathrm{M}$ guanidium thiocyanate, $100 \mathrm{mM}$ EDTA, and $0.5 \%$ sarkosyl) was added, and the sample was vortexed briefly. Transfer the mixture to an adsorption column (EZ500, Sangon Biotech Co., Ltd.). Next, $200 \mu \mathrm{L}$ wash buffer I (5.5 M guanidium thiocyanate, $0.5 \mathrm{M}$ Tris- $\mathrm{HCl}, \mathrm{pH} 8.0$, was added and the sample was centrifuged for $1 \mathrm{~min}$ at 12,000 $\mathrm{g}$. Residual liquid in the adsorption column was removed and $200 \mu \mathrm{L}$ washing buffer II $(0.4 \mathrm{M}$ $\mathrm{NaCl}, 50 \mathrm{mM}$ Tris- $\mathrm{HCl}, \mathrm{pH} 8.0,50 \mathrm{mM} \mathrm{MgSO}_{4}$ ) was added; the sample was centrifuged for 1 $\mathrm{min}$ at $12,000 \mathrm{~g}$ and the residual liquid in the adsorption column was removed. To the center of the adsorption column, $50 \mu \mathrm{L}$ sterile $\mathrm{ddH}_{2} \mathrm{O}$ was slowly added and the column was incubated for $15 \mathrm{~min}$ at $37^{\circ} \mathrm{C}$, followed by centrifugation for $1 \mathrm{~min}$ at $12,000 \mathrm{~g}$. The DNA solution was stored at $-20^{\circ} \mathrm{C}$.

\section{Assessment of quality and quantification of DNA}

Genomic DNA was analyzed by $2 \%$ agarose gel electrophoresis. The results were photographed after ethidium bromide staining. DNA concentration was determined using a NanoDrop ${ }^{\circledR}$ ND-1000 (NanoDrop, Wilmington, DE, USA) and DNA yield was calculated. To evaluate the purity of the extracted DNA, optical density values were measured at wavelengths of 230,260 , and $280 \mathrm{~nm}\left(\mathrm{~A}_{230}, \mathrm{~A}_{260}\right.$, and $\mathrm{A}_{280}$, respectively) and the $\mathrm{A}_{260 / 280}$ and $\mathrm{A}_{260 / 230}$ ratios were calculated. Absorption values of the DNA solutions were measured by full-spectrum wavelength scanning over a range of $220-320 \mathrm{~nm}$. The average ratio of $\mathrm{A}_{260 / 280}$ was calculated for each set of triplicate samples and was used to estimate the purity of extracted nucleic acids: samples with a mean $\mathrm{A}_{260 / 280}$ of 1.8-2.0 were considered to be free of contamination, those with $\mathrm{A}_{260 / 280}<1.8$ were considered to contain protein or other contaminants, and those with $\mathrm{A}_{260 / 280}>$ 2.0 were considered to be due to the presence of RNA. 


\section{Restriction enzyme digestion analysis}

$\lambda$ DNA (Sangon Biotech) was added to DNA samples that had been diluted with water (1-, 50-, 100-, 200-fold dilution) following purification using the 3 methods. The samples were digested using the restriction enzyme HindIII and then the inhibition of restriction enzyme digestion was assessed. The $20-\mu \mathrm{L}$ reaction contained different dilution of DNA, $10 \mathrm{U}$ HindIII, and $0.5 \mathrm{mg} \lambda \mathrm{DNA}$. Digestion was carried out for $1.5 \mathrm{~h}$ at $37^{\circ} \mathrm{C}$ and then for 2 min at $65^{\circ} \mathrm{C}$.

\section{Qualitative PCR analysis}

Primers used in this study included those specific for bacterial 16S rDNA.

The following bacterial primers were used: 27F: 5'-AGAGTTTGATCCTGGC TCAG-3', and 1492R: 5'-GGCTACCTTGTTACGACTT-3'. Amplification was carried out in a $50-\mu \mathrm{L}$ reaction volume containing $1 \mathrm{X}$ buffer $(50 \mathrm{mM} \mathrm{KCl}, 10 \mathrm{mM}$ Tris- $\mathrm{HCl}, \mathrm{pH} 8.3,1.5 \mathrm{mM}$ $\left.\mathrm{MgCl}_{2}\right), 2 \mu \mathrm{L}$ template DNA, $200 \mu \mathrm{M}$ dNTPs, $0.6 \mu \mathrm{M}$ of each primer, and $1.5 \mathrm{U}$ Taq DNA polymerase (Takara Biotechnology Co., Ltd., Dalian, China). All PCR amplifications were performed in a GeneAmp PCR 9700 system (Applied Biosystems, Foster City, CA, USA) using the following temperature program: $94^{\circ} \mathrm{C}$ for $5 \mathrm{~min}$, followed by 35 cycles at $94^{\circ} \mathrm{C}$ for $1 \mathrm{~min}, 61^{\circ} \mathrm{C}$ for $1 \mathrm{~min}, 72^{\circ} \mathrm{C}$ for $1 \mathrm{~min}$, and a final extension at $72^{\circ} \mathrm{C}$ for $7 \mathrm{~min}$. Amplified products were electrophoresed on a $2 \%$ agarose gel for approximately $20 \mathrm{~min}$ at $100 \mathrm{~V}$ and stained with ethidium bromide for visualization.

\section{RESULTS}

\section{Total DNA extraction and detection}

In an initial experiment, 50-mL freshwater samples were extracted using 3 methods according to the protocols outlined above. DNA extraction procedures for these methods were carried out in triplicate. Figure 1 shows that only the filtration-membrane method and modified filtration-membrane method were useful for extracting sufficient amounts of DNA to be detected by agarose gel electrophoresis, while no DNA was detected using the centrifugation method. The DNA yield using the centrifugation method was below detection range, which may have been because microbial communities could not be aggregated to a sufficient extent for DNA extraction, and this could only be achieved through centrifugation $(5000 \mathrm{~g}, 20 \mathrm{~min})$. Compared to the modified filtration-membrane method, the extracted DNA bands from the filtration-membrane method were brighter, indicating a higher concentration, and degraded. Degradation may have been the result of nuclease contamination. Lack of SDS lysis using the filtration-membrane method may have been because SDS inhibited nucleases by preventing their interaction with hydrophilic nucleic acids.

\section{DNA extraction yield and purity}

To examine the purity of the DNA extract, the UV absorption at 230, 260, and 280 $\mathrm{nm}$ were measured and the $\mathrm{A}_{260 / 230}$ and $\mathrm{A}_{260 / 280}$ ratios were calculated (Table 1). The filtrationmembrane method provided higher final DNA yield than the other methods. The DNA yield 
using the modified filtration-membrane method may have been lower than that of the filtration-membrane method because of the consecutive application of 2 steps of adsorption to the column during DNA purification. The amount of eluted DNA was reduced after purification on the adsorption column, and thus a 2nd application may have resulted in a higher loss of DNA (Knauth et al., 2013).

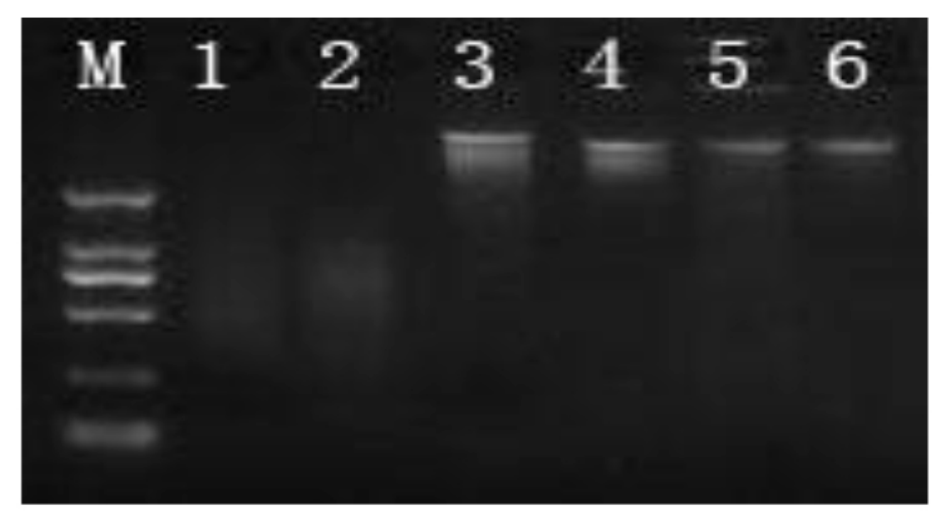

Figure 1. Agarose gel results showing total DNA extracted. Centrifugation method (lanes 1 and 2); filtrationmembrane method (lanes 3 and 4); modified filtration-membrane method (lanes 5 and 6 ); lane $M=$ DL2000 marker.

Table 1. Spectrophotometry results of total DNA extracted from water samples using 3 different extraction methods.

\begin{tabular}{lccc}
\hline Methods & DNA concentration $(\mu \mathrm{g} / \mathrm{mLwater})$ & Absorption ratio $\mathrm{A}_{260 / 280}$ & ${\text { Absorption ratio } \mathrm{A}_{260 / 230}}$ \\
\hline Centrifugation & $3.1 \pm 0.23$ & $1.72 \pm 0.25$ & $0.81 \pm 0.10$ \\
Filtration-membrane & $64.8 \pm 0.32$ & $1.66 \pm 0.10$ & $1.52 \pm 0.17$ \\
Modified filtration-membrane & $38.9 \pm 0.06$ & $1.88 \pm 0.13$ & $1.91 \pm 0.10$ \\
\hline
\end{tabular}

The $\mathrm{A}_{260 / 230}$ value of the DNA extract following the modified filtration-membrane method was 1.91 , while the $\mathrm{A}_{260 / 230}$ ratios of the DNA extract obtained using the other methods were lower, indicating the presence of co-purified contaminants, as described in the NanoDrop manual. The DNA extracted using the modified filtration-membrane method showed the highest purities based on the $\mathrm{A}_{260 / 230}$ and $\mathrm{A}_{260 / 200}$ ratios. The reason may be that this method involved a purification step with $5.5 \mathrm{M}$ guanidine thiocyanate, which was necessary to prevent inhibition of PCR.

\section{Effect of contaminants in extraction DNA on the restriction enzyme digestions}

$\lambda$ DNA digestion of DNA that had been diluted with water was accomplished using the restriction enzyme HindIII. Contaminants, such as acid, are known to interfere with restriction enzyme digestion and PCR amplification (Mangiapan et al., 1996; Bürgmann et al., 2001; Dong et al., 2006). Restriction digestion of $\lambda$ DNA produced clear bands, indicating that the restriction reaction could be carried out in diluted DNA samples. As shown in Figure 2, when $\lambda$ DNA was added to extracted DNA (1-fold dilution) obtained using the 3 described methods, 
only the modified filtration-membrane method sample was digested to produce clear bands, indicating that the least amount of contaminant was present in this sample. Meanwhile, for extracted DNA (50-, 100-, 200-fold dilution) using all 3 methods, the $\lambda$ DNA could be digested to produce clear bands. The reason may be that the contaminants in the extracted DNA were diluted by equal multiples, which did not inhibit restriction enzyme digestion.

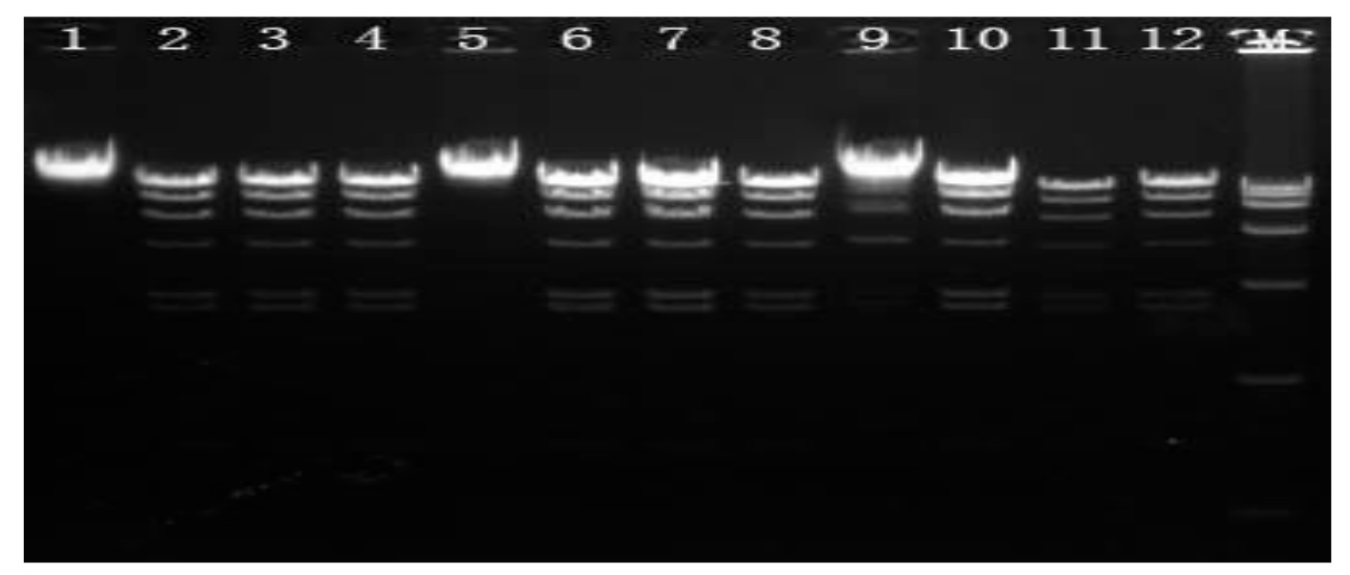

Figure 2. Restriction enzyme digestion patterns of $\lambda$ DNA adding dilutions of water DNA. $\lambda$ DNA enzyme digestion of diluted DNA samples (1-, 50-, 100-, 200-fold dilution) by centrifugation method (lanes 1-4); filtration-membrane method (lanes 5-8); modified filtration-membrane method (lanes 9-12); lane $M=\lambda \mathrm{DNA} /$ HindIII DNA marker.

\section{PCR analysis}

After evaluating the quality and quantity of DNA, PCR was used to amplify the $16 \mathrm{~S}$ rDNA of bacteria to produce a fragment of approximately $1450 \mathrm{bp}$. These samples were used to analyze the DNA obtained using the 3 methods. The results are shown in Figure 3.

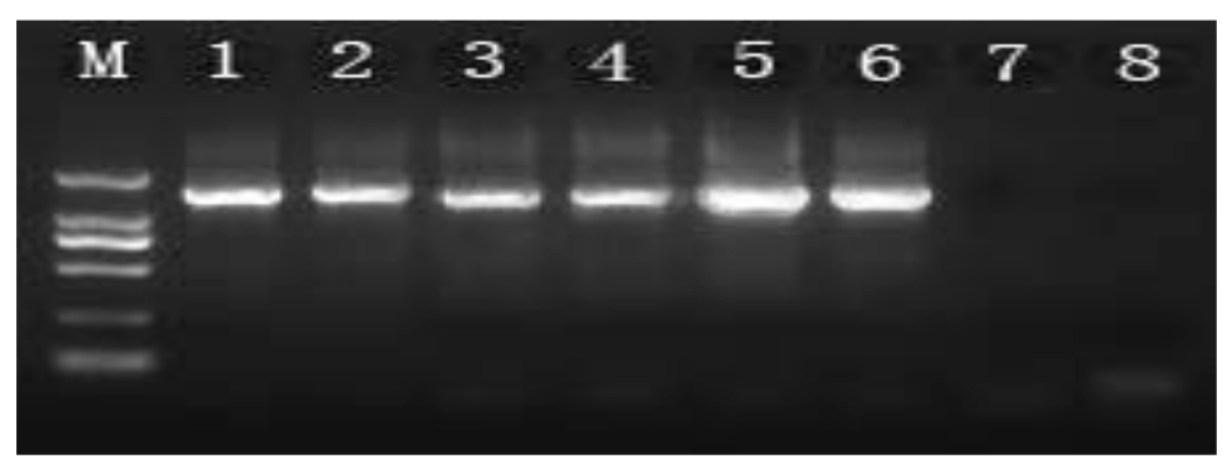

Figure 3. Agarose gel results showing PCR product amplification. Centrifugation method (lanes 1 and 2); filtrationmembrane method (lanes 3 and 4); modified filtration-membrane method (lanes 5 and 6); lane M= DL2000; no template control: lanes 7 and 8 . 
The PCR amplicons showed nearly equal results regarding DNA extraction regardless of which of the 3 methods was used. As shown in Table 1, the filtration-membrane method showed a higher final DNA yield, while PCR product amplification was lower than that using the modified filtration-membrane method. This may be because the DNA extracted using the filtration-membrane method contained more contaminating substances such as proteins, polysaccharides, and humic acid, which severely inhibited PCR amplification. The efficiency of PCR using DNA purified using the modified filtration-membrane method was the highest, indicating that this sample is the most suitable for use in molecular applications.

\section{DISCUSSION}

Acquiring quality genomic DNA samples is a key step in performing molecular applications involving genomic studies (Chacon-Cortes et al., 2012). Moreover, the components present in freshwater are very complex, containing humic acid, which is similar to nucleic acids in its physical and chemical characteristics. Therefore, humic acid and nucleic acids compete for binding the DNA precipitation or absorption sites of the purification column (Harry et al., 1999).

An ideal extraction method should fulfill the following 2 requirements: the amount of extracted DNA should be high and the extracted nucleic acids should be pure and intact, allowing for molecular biology studies to be performed. In the modified filtration-membrane method, the following techniques enhanced and optimized the extraction efficiency and purity. Using a $0.22-\mu \mathrm{m}$ filtration membrane in combination with zirconium beads is advantageous because the cells were disrupted not only in a chemical manner but also mechanically. The silica membrane of the absorption column was very important for DNA purification, while contaminant substances such as proteins and polysaccharides were efficiently removed. Therefore, these purification steps may be indispensable when the DNA will be used for PCR.

\section{CONCLUSIONS}

In this study, we compared 3 methods of extracting DNA from total freshwater microbial communities. The results showed that the modified filtration-membrane method was the most suitable for use in molecular applications.

\section{ACKNOWLEDGMENTS}

Research supported by the the Fund of Key Project of Science and Technology of the Shanghai Committee of Agriculture (\#2011-6-2), the Shanghai Postdoctoral Sustentation Fund (Grant \#13R21421000), the China Postdoctoral Science Foundation (Grant \#2013M531197), and the National Science and Technology Major Project of the Ministry of Science and Technology of China (\#2012ZX07101-009)

\section{REFERENCES}

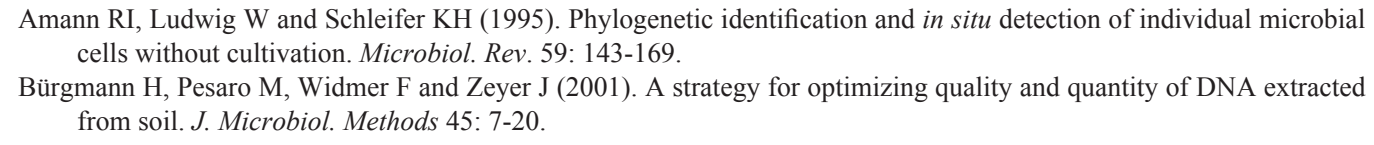


Chacon-Cortes D, Haupt LM, Lea RA and Griffiths LR (2012). Comparison of genomic DNA extraction techniques from whole blood samples: a time, cost and quality evaluation study. Mol. Biol. Rep. 39: 5961-5966.

Dong D, Yan A, Liu H, Zhang X, et al. (2006). Removal of humic substances from soil DNA using aluminium sulfate. $J$. Microbiol. Methods 66: 217-222.

Handelsman J (2004). Metagenomics: application of genomics to uncultured microorganisms. Microbiol. Mol. Biol. R 68: 669-685.

Harry M, Gambier B, Bourezgui Y and Garnier-Sillam E (1999). Evaluation of purification procedures for DNA extracted from organic rich samples: interference with humic substances. Analysis 27: 439-441.

Knauth S, Schmidt H and Tippkötter R (2013). Comparison of commercial kits for the extraction of DNA from paddy soils. Lett. Appl. Microbiol. 56: 222-228.

Mangiapan G, Vokurka M, Schouls L, Cadranel J, et al. (1996). Sequence capture-PCR improves detection of mycobacterial DNA in clinical samples. J. Clin. Microbiol. 34: 1209-1215.

Wu T, Sheng JP and Shen L (2010). Application of microbial molecular ecology techniques in microbial diversity of lake. Biotechnology 3: 62-66.

Ye WJ, Liu XL, Lin SQ, Tan J, et al. (2009). The vertical distribution of bacterial and archaeal communities in the water and sediment of Lake Taihu. FEMS Microbiol. Ecol. 70: 107-120.

Zhang SH, Xu WT, Shi H (2012). Comparison of the extraction methods of DNA and study on the biotechnological detection of Pseudomonas aeruginosa in river. Sci. Technol. Food Ind. 33: 375-379. 